\title{
HUBUNGAN KEKUATAN OTOT LENGAN DAN OTOT TUNGKAI DENGAN PRESTASI RENANG GAYA DADA 50 METER
}

\author{
Dedy Irawan ${ }^{1)}$, Muhammad Nidomuddin ${ }^{2)}$ \\ IKIP Budi Utomo Malang \\ Email: 1 dedyirawan@budiutomomalang.ac.id \\ ${ }^{2}$ nidomuddinpjkr@budiutomomalang.ac.id
}

\begin{abstract}
ABSTRAK
Penelitian ini bertujuan untuk mengatahui hubungan antara kekuatan otot lengan $\left(\mathrm{X}_{1}\right)$,kekuatan otot tungkai $\left(\mathrm{X}_{2}\right)$ dengan prestasi Renang gaya kupu-kupu 50 Meter $(\mathrm{Y})$. Penelitian ini merupakan penelitian korelasi dengan tujuan menghubungkan antara variabel bebas dan variabel terikat. Teknik pengumpulan data menggunakan teknik tes dan pengukuran, teknik analisa data menggunakan statistik korelasi product moment dengan taraf signifikan 5\%. Hasil analisa korelasi antara Kekuatan otot lengan $\left(\mathrm{X}_{1}\right)$ dengan prestasi Renang (Y) di peroleh sebesar 0,012 dan pada taraf signifikan 5\% sebesar 0,301 Hasil analisa korelasi antara kekuatan otot tungkai $\left(\mathrm{X}_{2}\right)$ dengan prestasi Renang gaya kupu-kupu (Y) diperoleh sebesar 0,051dan pada taraf signifikan 5\% sebesar 0,301. Sedangkan analisis korelasi bersama-sama antara kekuatan otot lengan $\left(\mathrm{X}_{1}\right)=0,012$ pada taraf singnifikan $5 \%$ $(0,301)$ dan kekuatan otot tungkai $\left(\mathrm{X}_{2}\right)=0,051$ dengan prestasi renang gaya kupu-kupu 50 Meter (Y) diperoleh sebesar $(7,27)$ dan pada taraf signifikan 5\% sebesar $(0,301)$.
\end{abstract}

Kata Kunci : Kekuatan Otot Lengan, Kekuatan Otot Tungkai, dan Prestasi Renang Gaya Dada 50 Meter.

\begin{abstract}
This study aims to determine the relationship between arm muscle strength (X1), leg muscle strength (X2) with the achievement of 50 Meter Butterfly Pool (Y). This research is a correlation research with the aim of connecting between independent variable and dependent variable. Technique of collecting data using test and measurement techniques, data analysis techniques using product moment correlation statistics with a significant level of 5\%. The result of correlation analysis between arm muscle strength (X1) with achievement of Pool (Y) was obtained by r_hitung equal to 0,012 and r_tabel at 5\% significant level 0,301 Result of correlation analysis between leg muscle strength (X2) with Achievement of Butterfly Pool (Y) obtained $r$ hitung equal to 0,051 and $r_{-}$tabelpada significant level 5\% equal to 0,301 . While the correlation analysis together between arm muscle strength $(\mathrm{X} 1)=0.012$ on a significant level of 5\% r_table (0.301) and leg muscle strength $(\mathrm{X} 2)=0.051$ with the 50 meter butterfly pool achievement (Y) obtained by F_count of ( 7.27) and F_tabel at a significant level of $5 \%$ of $(0.301)$
\end{abstract}

Keywords: Muscle Sleeve Strength, Limb Muscle Strength, and 50 Meter Breaststroke Achievement. 


\section{PENDAHULUAN}

Kegiatan olahraga menurut UU RI Nomor 3 Tahun 2005 tentang sistem pendidikan olahraga nasional adalah "bahwa keolahragaan nasional bertujuan memelihara dan meningkatkan kesehatan dan kebugaran, prestasi, kualitas manusia, menanamkan nilai moral dan akhlak mulia, sportivitas, disiplin, mempererat dan membina persatuan dan kesatuan bangsa, memperkokoh ketahanan nasional, serta mengangkat harkat, martabat dan kehormatan bangsa".

Diantara sekian banyak olahraga yang ada di dunia, Renang merupakan suatu cabang olahraga tertua dan juga dianggap sebagai induk dari semua cabang olahraga. Atletik sejak jaman dulu secara tidak sadar telah dilakukan orang seperti berjalan, berlari, melompat, melempar, menombak saat berburu dalam kehidupan sehari-hari. Di Indonesia cabang olahraga atletik merupakan bidang studi olahraga yang tercantum dalam garis - garis besar program pengajaran (GBPP), yang harus diberikan kepada setiap jenjang pendidikan formal.

Olahraga di pihak lain adalah suatu bentuk bermain yang terorganisir dan bersifatkompetitif. Beberapa ahli memandang bahwa olahraga sematamata suatu bentuk permainan yang terorganisir, yang menempatkannya lebih dekat pada istilah pendidikan jasmani. Akan tetapi, pengujian yang lebih cermat menunjukkan bahwa secara tradisional, olahraga melibatkan aktivitas kompetitif.'(H.J.S Husdarta,2009)."

Olahraga renang sangat berbeda dengan olahraga yang lain dan bergerak di air berbeda dengan bergerak di darat. Gerak manusian di darat pada umumnya pada posisi tegak atau vertical di pengaruhi daya tarik bumi sepenuhnya, sedangkan perenang yang bergerak di air dalam posisi horisontal di bawah pengaruh daya tarik bumi dikurangi oleh daya tekanan air ke atas.

Dalam keadaan normal, kita dapat bergerak agak bebas di bawah daya tarik bumi, sedangkan di dalam air kita harus belajar menyesuaikan gerakan kita dengan air. Hal tersebut yang menyebabkan terjadinya gerakan-gerakan yang nampaknya aneh lama kelamaan terciptalah gerakan-gerakan tertentu yang dianggap paling menguntungkan bagi sesorang pada waktu berenang baik ditinjau dari segi mudahnya gerakan itu dilakukan, maupun dari segi cepatnya melaju ke depan . gerakan-gerakan tertentu ini kemudian menjadi gaya-gaya renang tertentu gerakannya semakin menjadi mentap dan 
mempunyai cirri-ciri khusus, seperti gerakan-gerakan yang terdapat pada gaya dada, gaya bebas, gaya punggung, dan gaya kupu-kupu.

Pencapaian hasil atau prestasi yang diharapkan di tengah ketatnya persaingan olahraga renang tidaklah mudah banyak faktor yang menentukan majunya suatu prestasi, misalnya faktor: panjang lengan, tinggi badan, panjang tungkai (anatomi), kemampuan menghirup oksigen, kelincahan, keseimbangan, koordinasi, kekuatan, power, fleksibilitas (fisiologi), kecepatan gerak, dan frekuensi kayuhan (biomekanika), kepribadian, atribusi, motivasi, agresi, arausal, kecemasan, stress, aktivasi, kepemimpinan, komunikasi, imagery, konsentrasi, dan rasa percaya diri (psikologi).

Motivasi berprestasi merupakan suatu dorongan yang terdapat dalam diri seseorang untuk selalu berusaha meningkatkan kemampuannya dengan menggunakan standar keunggulan. Motivasi berprestasi yang dimiliki atlet cenderung akan mempengaruhi kinerjanya terhadap prestasi renang $50 \mathrm{~m}$ dalam perlombaan.

Seiring dengan perkembangan jaman Olahraga Renang ini juga sudah di kenal oleh masyarakat Indonesia sejak dulu terutama oleh masyarakat sekolah sehingga tidak heran jika nomor ini selalu diperlombakan dalam event - event olahraga di Indonesia mulai dari tingkat SD, SMP, SMA, dan perguruan tinggi, sehingga untuk nomor Renang sering dipertandingkan dari tingkat daerah, nasional, maupun tingkat dunia.

Olahraga renang terdiri dari empat gaya yang diperlombakan, yaitu: gaya kupu-kupu, gaya punggung, gaya dada, dan gaya bebas. Dari beberapa unsur penunjang tersebut dan nomor-nomor perlombaan dalam olahraga renang, khususnya nomor perlombaan jarak 50m diperlukan sekali motivasi berprestasi.dan dalam penelitian ini peneliti mengambil dari salah satu ke empat gaya tersebut yaitu gaya dada dengan judul hubungan kekuatan otot lengan dan otot tungkai dengan prestasi renang gaya dada 50 meter pada mahasiswa kelas B Ikip Budi Utomo Malang.

Kekuatan merupakan komponen dasar dalam melakukan setiap aktivitas fisik, termasuk olahraga. Untuk dapat melakukan keterampilan fisik yang baik, kekuatan otot merupakan salah satu komponen penting yang harus di miliki terlebih dahulu. Dengan kata lain, kekuatan merupakan komponen dasaryang harus di miliki sebelum mengembangkan kemampuan fisik lainnya. 
Kekuatan umum adalah pondasi bagi seluruh program latihan kekuatan. Ini difokuskan ada tahap awal latihan dan ini disebut tahap adaptasi anatomis, diberikan pada Tahap Persiapan (Preparation Period). Untuk mencapai penampilan puncak latihan harus direncanakan dan dibuat periodesasi dengan membuat latihan secara bertahap-tahap, sehingga mendorong kepada tingkatan-tingkatan yang paling tinggi selama musim kompetisi. Latihan kekuatan harus didasarkan pada persyaratan-persyaratan fisiologis yang spesifik dari cabang olahraga dan harus mampu untuk mengembangkan power dan daya tahan otot

Daya ledak atau power merupakan komponen kondisi fisik yang didalamnya terdapat dua unsur pokok yaitu kekuatan dan kecepatan. Berkaitan dengan power, Suharno (1993:95) menyatakan "eksplosive power adalah kemampuan otot atlet untuk mengatasi tahan beban dengan kekuatan dan kecepatan maksimal dalam satu gerakan utuh". Sudjarwo (1993:27) menyatakan "eksplosive power merupakan kemampuan otot (segerombolan otot) untuk melawan beban/tahanan dengan kecepatan tinggi dalam satu gerakan (Penggunaan Force \& Velocity)“. Lengan merupakan anggota gerak atas yang terdiri dari seluruh lengan, mulai dari pangkal lengan sampai ujung jari tangan. Rangka dari pada anggota gerak atas dibagi menjadi 3 bagian besar: (1) sceletion brachii, (2) sceletion ante brachii, (3) sceletion mani".

Kekuatan otot merupakan unsur penting untuk menggerakkan organorgan tubuh. Tanpa kekuatan otot yang besar, tidak akan tercapai prestasi yang maksimal. Biasanya seorang atlet mempunyai keunggulan jauh lebih besar dibandingkan dangan orang kebanyakan. Golongan ini biasanya mempunyai tipe fisik yang disebut mesomorphy. Mereka mempunyai badan yang bagus, dan secara umum mereka disebut atletis menurut Suharno, H.P "Kekuatan otot adalah kemampuan seseorang untuk melakukan kekuatan maksimal dengan kecepatan tinggi dalam suatu gerakan utuh dan dikoordinasikan" (Suharno H.P, 1993:283)

Meskipun pada juara sepak bola: bola basket, gymnastik, renang (dan dalam cabang-cabang olahraga lainnya), seringkali mempunyai keunggulan genetic yang bersifat pembawaan. Baik dalam berat badan, kepadatan dan ketebalan tulang, ukuran bagian lainnya (misalnya tangan dan tungkai pada pemain sepak bola) maupun ciri psikologisnya, mereka mempunyai persamaan dalam satu hal, mereka berkekuatan dan bertenaga yang besar, mereka berkekuatan besar karena mempunyai kualitas genetic yang 
disebut mesomorphy".Mengacu pada definisi tersebut di atas maka kesegaran jasmani mempunyai beberapa unsur, yaitu:( a) Strenght (kekuatan) (b)Power (daya ledak = kekuatan + kecepatan) (c.) Speed (kecepatan) (d) Flexibility (kelenturan) (e.) Agility (kelincahan) (f). Endurance (daya tahan).

Gaya dada merupakan gaya yang paling menarik karena tidak lekas melelahkan bila dibandingkan dengan gaya yang lain, karena proses pernafasan berlangsung dengan mudah sehingga lebih mudah dipergunakan dalam berenang jarak jauh dan santai. Renang gaya dada sering juga disebut renang katak karena gaya dada tersebut mirip sekali dengan gerakan katak pada waktu berenang (Syarifudin Aip, 1979).

\section{METODE}

Didalam suatu penelitian metode penelitian mempunyai arti penting. Suatu hasil penelitian dianggap ilmiah apabila menggunakan metode yang berlaku di dalam suatu pengetahuan. Tidak semua metode di dalam penelitian efektif digunakan untuk mendapatkan dan memperoleh hasil di dalam pengolahan data yang sudah terkumpul, akan tetapi setiap penelitian hanya ada beberapa metode yang sesuai dengan obyek penelitian. Pada bagian lain (Sutrisno Hadi 1989) mengatakan bahwa: "Studi korelasi merupakan studi untuk mengamati ada tidaknya hubungan dua variabel atau lebih, jika ada seberapa derajad hubungannya".

Penelitian ini merupakan penelitian korelasi yaitu penelitian yang mencari hubungan antara hubungan kekuatan otot lengan dan otot tungkai dengan prestasi renang gaya dada 50 meter pada mahasiswa kelas B Ikip Budi Utomo Malang. Untuk lebih jelasnya skema atau rancangan penelitian studi korelasi secara ilustratif dapat dilihat pada bagan di bawah ini:

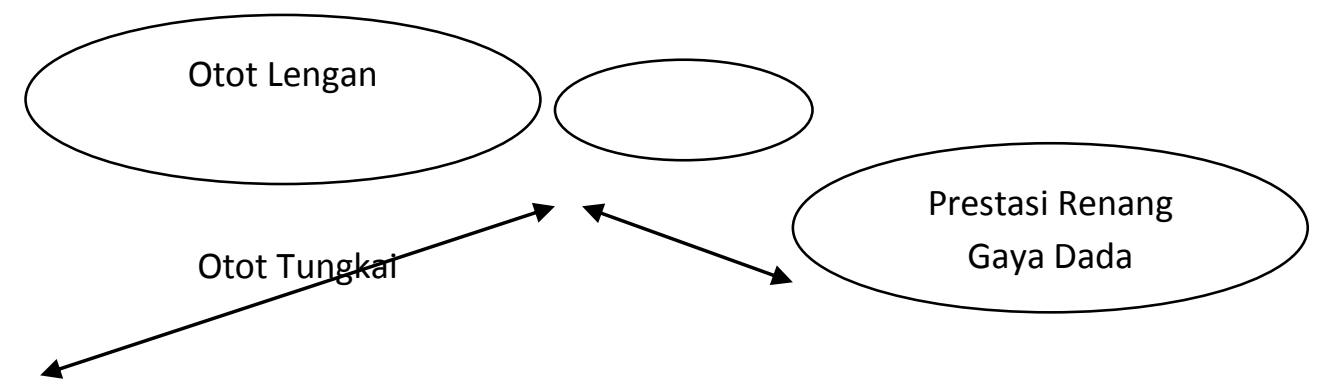


Instrumen penelitian yang dilakukan yaitu diantaranya melakukan tes pull up selama 60 detik yang dilakukan pada palang pegangan yang terbuat dari esi atau pipa dengan ketinggian sesuai dengan tinggi badan perserta, berikutnya tes squat jump selama 60 detik, untuktes yang terakhir adalah tes renang gaya dada,

Tabel 1. Kriteria Penilaian

\begin{tabular}{|l|l|l|l|}
\hline Skor & Putra & Criteria & Putri \\
\hline 5 & $>38$ & Sempurna & $>17$ \\
\hline 4 & $29-37$ & Baik sekali & $13-16$ \\
\hline 3 & $20-28$ & Baik & $9-12$ \\
\hline 2 & $15-19$ & Cukup & $5-8$ \\
\hline 1 & $4-14$ & Kurang & $1-4$ \\
\hline
\end{tabular}

Menurut (Suharsimi Arikuno, 1998) dijelaskan bahwa untuk sekedar ancer - ancer maka apabila subyeknya kurang dari 100, maka lebih baik diambil semua sehingga penelitian ini merupakan penelitian populasi. Selanjutnya jika subyeknya besar dapat diambil antara $10 \%$ sampai $15 \%$ atau $20 \%$ sampai $25 \%$ atau lebih tergantung kemampuan peneliti. Pelaksanaan pengumpulan dan pengambilan data dalam penelitian ini menggunakan teknik tes dan pengukuran. Tes adalah alat atau instrument yang digunakan untuk memperoleh informasi tentang seseorang atau obyek (Arman Abdoellah, 1984). Tes ini dipergunakan untuk mengumpulkan data yang berasal dari variabel - variabel bebas yang meliputi ; kekuatan Otot Lengan detik/sekon (s), dan kekuatan otot tungkai (lompat tanpa awalan) dalam satuan meter (m) dan Prestasi Renang Gaya Dada dalam satuan meter/detik(S). Pengukuran adalah proses pengumpulan data atau informasi melalui pengukuran dapat di tentukan kedudukan atau status sekarang dari mahasiswa. Pemberian sebuah tes adalah bagian dari proses pengukuran. (Arman Abdoellah, 1984). Pengukuran ini dimaksudkan sebagai cara untuk mengumpulkan data yang berasal dari variabel terikat berupa hasil pengukuran kemampuan sampel melakukan lompat jauh dalam satuan meter (m) yang sudah standar

Kedua bentuk pengumpulan data tersebut pelaksanaanya berupa praktek langsung di lapangan. Dari data pengumpulan tes jenisnya meliputi: 
kekuatan otot lengan, kekuatan otot tungkai. Sedangkan pengukuran dengan cara mengambil data dari prestasi renang gaya dada yang di lakukan sampel dengan menggunakan satuan meter $(\mathrm{m})$

\section{HASIL DAN PEMBAHASAN}

Dari pengelolaan data yang di peroleh mean dan standar deviasi dari masing - masing variabel sebagai berikut:

Tabel 2. Mean dengan standart deviasi dari masing-masing variabel

Descriptive Statistics

\begin{tabular}{|l|r|r|r|r|r|}
\hline & N & Minimum & Maximum & \multicolumn{1}{c|}{ Mean } & Std. Dev iation \\
\hline Renang Gay a Dada (Y) & 40 & 1.18 & 2.31 & 1.3828 & .20000 \\
Restoke (X1) & 40 & 9 & 14 & 11.80 & 1.522 \\
Skot Jump (X2) & 40 & 23 & 35 & 28.45 & 3.186 \\
Valid N (listwise) & 40 & & & & \\
\hline
\end{tabular}

Keterangan

$\mathrm{X}_{1}=$ Kekuatan Otot Lengan $(\mathrm{X} 1)$

$\mathrm{X}_{2}=$ Kekuatan Otot Lengan $(\mathrm{X} 2)$

$\mathrm{Y}=$ Prestasi Renang Gaya Dada $(\mathrm{Y})$

Hasil korelasi atau hubungan antara dua variabel bebas dan variabel terikat, yaitu hubungan antara Kekuatan Otot Lengan dan kekuatan otot tungkai dengan prestasi Prestasi Renang Gaya Dada pada Mahasiswa Putra kelas B Jurusan Pendidikan Jasmani Kesehatan dan Rekreasi IKIP Budi Utomo Malang angkatan 2017 tercantum dalam tabel berikut:

Tabel 3. Korelasi antara variabel bebas dan variabel terikat

\begin{tabular}{|c|c|c|c|}
\hline Variabel & rxy Hitung & r Tabel & Keterangan \\
\hline $\mathrm{X}_{1}$ & 0,012 & 0,0312 & Adahubungan \\
$\mathrm{X}_{2}$ & 0,051 & 0,312 & Adahubungan \\
\hline
\end{tabular}

Keterangan

$\mathrm{X}_{1} \quad=$ kekuatan otot lengan

$\mathrm{X}_{2} \quad=$ Kekuatan Otot Tungkai

$\mathrm{rX}_{1} \mathrm{y}=$ Nilai korelasi antara kekuatan otot lengan dengan prestasi renang $\mathrm{rX}_{2} \mathrm{y}=$ Nilai korelasi antara kekuatan otot tungkai dengan prestasi renang 
Korelasi kekuatan otot lengan (x1) dengan prestasi renang (y)

\section{Correlations}

\begin{tabular}{|ll|r|r|}
\hline & & t renang & trestoke \\
\hline t_renang & Pearson Correlation & 1 & -.012 \\
& Sig. (2-tailed) & & .943 \\
& $\mathrm{~N}$ & 40 & 40 \\
\hline t_restoke & Pearson Correlation & -.012 & 1 \\
& Sig. (2-tailed) & .943 & \\
& $\mathrm{~N}$ & 40 & 40 \\
\hline
\end{tabular}

Korelasi kekuatan otot lengan (x1) dengan prestasi renang (y)

\section{Correlations}

\begin{tabular}{|ll|r|r|}
\hline & & t renang & t skotjump \\
\hline t_renang & Pearson Correlation & 1 & -.051 \\
& Sig. (2-tailed) & & .754 \\
& $\mathrm{~N}$ & 40 & 40 \\
\hline t_skotjump & Pearson Correlation & -.051 & 1 \\
& Sig. (2-tailed) & .754 & \\
& $\mathrm{~N}$ & 40 & 40 \\
\hline
\end{tabular}

Korelasi Kekuatan Otot Lengan (x1) Korelasi Kekuatan Otot Tungkai (x2) dengan Prestasi Renang (y)

Coefficients ${ }^{\mathrm{a}}$

\begin{tabular}{|rl|r|r|r|r|r|}
\hline \multirow{2}{*}{ Model } & \multicolumn{2}{|c|}{$\begin{array}{c}\text { Unstandardized } \\
\text { Coeff icients }\end{array}$} & \multicolumn{2}{c|}{$\begin{array}{c}\text { Standardized } \\
\text { Coeff icients }\end{array}$} & & \\
\cline { 3 - 5 } & & \multicolumn{1}{|c|}{$\mathrm{B}$} & Std. Error & \multicolumn{1}{|c|}{ Beta } & \multicolumn{1}{c|}{$\mathrm{t}$} & \multicolumn{1}{c|}{ Sig. } \\
\hline 1 & (Constant) & 52.925 & 11.330 & & 4.671 & .000 \\
& t_restoke & -.008 & .165 & -.008 & -.049 & .962 \\
& t_skotjump & -.051 & .165 & -.051 & -.307 & .761 \\
\hline
\end{tabular}

a. Dependent Variable: t_renang

Koefisien korelasi antara kekuatan otot lengan (x1) dan otot tungkai (x2) dengan prestasi renang di peroleh $r_{\text {hitung }}(\mathrm{x} 1)(0,008)$ pada taraf singnifikan $5 \% r_{\text {tabel }}(0,312)$. Oleh karena itu $r_{\text {hitung }}$ lebih besar dari pada $r_{\text {tabel }}$, maka hipotesis nihil (Ho) yang berbunyi tidak ada hubungan antara kekuatan otot lengan dan kekuatan otot tungkai dengan prestasi renang ditolak dan hipotesis alternatif (Ha) ada hubungan antara kekuatan otot lengan dan 
kekuatan otot tungkai dengan prestasi renang dapat di terima, berarti ada hubungan antara kekuatan otot lengan dan kekuatan otot tungkai dengan prestasi renang variabel bebas ada hubungan yang signifikan

\section{SIMPULAN}

Berdasarkan dari hasil penelitian ini yang pada akhirnya menyatakan bahwa ada hubungan yang signifikan kekuatan otot lengan dan kekuatan otot tungkai dengan prestasi renang gaya dada pada Mahasiswa Putra kelas B Jurusan Pendidikan Jasmani Kesehatan dan Rekreasi IKIP Budi Utomo Malang angkatan 2017. Untuk para mahasiswa khususnya supaya lebih giat lagi melatih otot-otot yang menunjang dalam renang gaya dada, gaya bebas, maupun gaya punggung guna untuk mengasah skil dari praktek maupun paham akan kemampuan secara teori.

\section{DAFTAR PUSTAKA}

Abdoellah Arman,1984,"Pembuatan Alat Evaluasi Keterampilan Olahraga", Depdikbud P2LPTK Jakarta.

Arikunto Suharsimi, 1998, "Dasar - Dasar Evaluasi Pendidikan Edisi Revisi”, Bumi Aksara, Jakarta.

H.J.S.Husdarta.2009.Manajemen pendidikan jasmani. Bandung. Alfabeta

Sutrisno Hadi, 1989, "statistik", Jilid II Fakultas Psychologi UGM, Yogyakarta.

Suharno H.P, 1993, "Ilmu Coaching Umum”, FPOK IKIP Yogyakarta

Sudjarwo,1993, ”Ilmu Kepelatihan Dasar. Surakarta” : Universitas Sebelas Maret CV, Alfabeta Bandung.

Syarifudin Aip, 1979, "Pendidikan Jasmani dan Olahraga”, CV Baru Jakarta. 